\title{
Quercetin Inhibits Cell Migration and Invasion in Human Osteosarcoma Cells
}

\author{
Haifeng Lan ${ }^{\mathrm{a}}$ Wei Hong ${ }^{\mathrm{b}}$ Pan Fan ${ }^{\mathrm{a}}$ Dongyang Qian ${ }^{\mathrm{a}} \quad$ Jianwei Zhu ${ }^{\mathrm{c}}$ Bo Baia \\ aDepartment of Orthopaedic Surgery, 1st Affiliated Hospital of Guangzhou Medical University, \\ Guangdong Provincial Key Lab of Orthopaedic Technology and Implant Materials, Guangzhou,

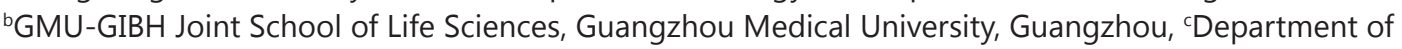 \\ Orthopaedics, Guangzhou First People's Hospital, Guangzhou Medical University, Guangzhou, China
}

\author{
Key Words \\ Quercetin • Migration • Invasion • Osteosarcoma
}

\begin{abstract}
Background/Aims: Osteosarcoma is a malignant tumor associated with high mortality; however, no effective therapies for the disease have been developed. Several studies have focused on elucidating the pathogenesis of osteosarcoma and have aimed to develop novel therapies for the disease. Quercetin is a vital dietary flavonoid that has been shown to have a variety of anticancer effects, as it induces cell cycle arrest, apoptosis, and differentiation and is involved in cell adhesion, metastasis and angiogenesis. Herein, we aimed to investigate the effects of quercetin on osteosarcoma migration and invasion in vitro and in vivo and to explore the molecular mechanisms underlying its effects on osteosarcoma migration and invasion. Methods: Cell viability, cell cycle activity and cell apoptosis were measured using CCK-8 assay and flow cytometry, and cell migration and invasion were evaluated by wound healing and transwell assays, respectively. The mRNA and protein expression levels of several proteins of interest were assessed by real-time quantitative PCR and western blotting, respectively. Moreover, a nude mouse model of human osteosarcoma lung metastasis was established to assess the anti-metastatic effects of quercetin in vivo. Results: We noted no significant differences in cell cycle activity and apoptosis between HOS and MG63 cells and control cells. Treatment with quercetin significantly attenuated cell migration and invasion in HOS and MG63 cells compared with treatment with control medium. Moreover HIF-1 $\alpha$, VEGF, MMP2, and MMP9 mRNA and protein expression levels were significantly downregulated in HOS cells treated with quercetin compared with HOS cells treated with controls. Additionally, treatment with quercetin attenuated metastatic lung tumor formation and growth in the nude mouse model of osteosarcoma compared with treatment with controls. Conclusion: Our findings regarding the inhibitory effects of quercetin on cell migration and invasion suggest that quercetin may have potential as a therapy for human osteosarcoma.
\end{abstract}




\section{Introduction}

As the most common primary malignant tumor of bone, osteosarcoma is highly prevalent in children and adolescents [1]. The ability of osteosarcoma to invade local tissues and migrate to distant sites indicates that the disease is highly malignant. The 5-year survival rate for localized osteosarcoma ranges from 60-70\%, and the disease is treated with traditional chemotherapy combined with surgery [2]; however, the survival rate for osteosarcoma decreases significantly to $<30 \%$ in cases in which the tumor metastasizes to other organs, especially the lung [3]. Furthermore, patients with metastatic osteosarcoma respond poorly to current conventional chemotherapeutic agents $[4,5]$. Thus, studies aiming to develop novel therapies to improve disease treatment are urgently needed [6].

Quercetin $\left(\mathrm{C}_{15} \mathrm{H}_{10} \mathrm{O}_{7}\right)$, a bioactive flavonoid, is naturally present in many commonly consumed foods. Because of its lipophilic nature, quercetin can cross the cell membrane and trigger various intracellular pathways involved in chemoprevention. Quercetin has a variety of effects in humans. For example, the compound has been reported to have antioxidant [7], antiaging [8], antidiabetic [9], and antifungal [10] effects and to regulate gastrointestinal (GI) motor activity [11]. Accumulating evidence indicates that quercetin also has anticancer effects [12-16], although only a few studies have described the effects of quercetin in osteosarcoma.

Hypoxia-inducible factor (HIF)- $1 \alpha$ has been identified in different types of human cancer [17-19] and is regarded as one of the key promoters of tumor metastasis [20]. HIF-1 $\alpha$ overexpression is correlated with a poor prognosis, an increased risk of metastasis, and decreased survival in patients with cancer [21, 22]. Moreover, HIF-1 $\alpha$ also regulates the expression of many downstream genes, including those encoding vascular endothelial cell growth factor (VEGF) [23] and the matrix metalloproteinases (MMPs) [24]. Therefore, HIF-1 $\alpha$ has been considered a novel therapeutic target for the treatment of cancer, and targeted therapies designed to modulate HIF-1 expression in cancer have recently been investigated $[25,26]$. VEGF, which is induced by HIF-1 $\alpha$, can be secreted by tumor cells and may serve as an important regulator of cell proliferation and metastasis in several types of tumors $[27,28]$, and MMPs play a critical role in tissue remodeling during tumor invasion and metastasis [29, 30]. MMPs degrade the molecules constituting the extracellular matrix (ECM), thereby promoting tumor progression and invasion [31]. Of the more than 20 known human MMPs, MMP2 and MMP9 seem to play crucial roles in tumor invasion due to their ability to degrade the ECM and basement membrane [32], and decreases in MMP2 and MMP9 expression and activity have been observed to inhibit cell growth and metastasis in a variety of cancer cell lines [33-37].

The present study was undertaken to explore the effects of quercetin on cell migration and invasion in a human osteosarcoma cell line. Here, we demonstrated that quercetin inhibited HOS cell migration and invasion in osteosarcoma by regulating HIF$1 \alpha$, VEGF, MMP2 and MMP9 expression in vitro and that quercetin ameliorated tumor metastasis in vivo in the osteosarcoma nude mouse model. Taken together, these results suggest that quercetin may be an effective therapy for osteosarcoma.

\section{Materials and Methods}

\section{Cell culture}

The human osteosarcoma cell lines HOS and MG63 were purchased from the American Type Culture Collection (ATCC, VA, USA; CRL-1543 ${ }^{\mathrm{TM}}, \mathrm{CRL}-1427^{\mathrm{TM}}$ ) and cultured in the recommended medium supplemented with $10 \%$ fetal bovine serum (FBS; Gibco, USA) at $37^{\circ} \mathrm{C}$ in a humidified atmosphere with $5 \%$ $\mathrm{CO}_{2}$. Quercetin (purity, $\geq 95 \%$ ) was purchased from Sigma-Aldrich (St Louis, MO, USA), dissolved in dimethyl sulfoxide (DMSO) and then diluted in medium immediately before use. The cells were treated with various concentrations of quercetin $(25,50$, and $100 \mu \mathrm{M})$ prior to being subjected to various assays. In this study, negative control cells $(0 \mu \mathrm{M})$ were treated with culture medium containing $0.1 \%$ DMSO. 


\section{Cell viability assay}

To evaluate the cytotoxic effects of quercetin on HOS and MG63 cells, we performed Cell Counting Kit-8 (CCK-8) assay (Dojindo Laboratories, Kumamoto, Japan). Briefly, the cells were seeded in a 24-well plate at a density of 50000 cells/well. After incubating for $6 \mathrm{~h}$, the cells were treated with quercetin at different concentrations $(0,25,50$, and $100 \mu \mathrm{M})$ and then incubated for $12 \mathrm{~h}$ and $24 \mathrm{~h}$. CCK-8 solution (100 $\mu \mathrm{l}$ ) was subsequently added to each well for $2 \mathrm{~h}$, after which the absorbance at $450 \mathrm{~nm}$ was measured using a microplate spectrophotometer (Thermo Scientific, Rockford, IL, USA). Cell viability was calculated with the following formula: cell viability (\%) $=$ (average absorbance of treated group - average absorbance of blank) $/$ (average absorbance of untreated group - average absorbance of blank) $\times 100 \%$.

\section{Flow cytometry}

The cells were seeded in a 24 -well plate at a density of $5 \times 10^{4}$ cells/well and then exposed to quercetin for $24 \mathrm{~h}$. For cell cycle assay, 10 plates of cells were harvested and washed with PBS, which had a temperature of $4{ }^{\circ} \mathrm{C}$, and then the precipitated cells were resuspended with $2 \mathrm{ml}$ of $70 \%$ ethanol overnight at $4{ }^{\circ} \mathrm{C}$. The cells were subsequently washed with $4{ }^{\circ} \mathrm{C}$ PBS again before being incubated with propidium iodide (PI) (50 $\mu \mathrm{g} / \mathrm{ml})$, RNase A $(100 \mu \mathrm{g} / \mathrm{ml})$ and $0.2 \%$ Triton X-100 complexes in the dark for $30 \mathrm{~min}$ at $4{ }^{\circ} \mathrm{C}$. The stained cells were then analyzed with flow cytometry. Apoptotic cells were identified using an Annexin V-fluorescein Isothiocyanate (FITC)/PI Cell Apoptosis Kit (Invitrogen), according to the manufacturer's protocol. Briefly, the cells were washed, after which they were incubated with $100 \mu \mathrm{l}$ of $1 \times$ annexin binding buffer containing $5 \mu \mathrm{l}$ of annexin V-FITC and $1 \mu \mathrm{l}$ of PI in the dark for $15 \mathrm{~min}$ before being analyzed with flow cytometry within the subsequent $30 \mathrm{~min}$.

\section{Cell migration assay (wound healing assay)}

HOS and MG63 cells were seeded $\left(5 \times 10^{4}\right.$ cells/well) in 24 -well plates in the appropriate culture medium. The cells were grown to $80 \%$ confluency, rinsed with phosphate-buffered saline (PBS), and then starved for $6 \mathrm{~h}$ in serum-free medium. A sterile 200- $\mu$ l pipette tip was subsequently used to create wounds, after which all the wells were washed with media to remove cell debris. The cells were then treated with 0 , 25,50 and $100 \mu \mathrm{M}$ quercetin. Images were captured with an inverted microscope at different time points $(0,12$, and $24 \mathrm{~h})$ post-quercetin administration.

\section{Cell invasion assay (transwell assay)}

Cell invasion was assessed using transwell cell culture chambers, according to the manufacturer's protocol. We used 24-well BioCoat cell culture inserts (BD Biosciences, Bedford, MA, USA) with a polyethylene terephthalate membrane (8- $\mu \mathrm{m}$ porosity) coated with Matrigel Basement Membrane Matrix $\left(100 \mu \mathrm{g} / \mathrm{cm}^{2}\right.$; $\mathrm{BD}$ ). The membranes of each upper chamber were coated with Matrigel (BD) and then incubated for 6 $\mathrm{h}$ at $37^{\circ} \mathrm{C}$. Before each assay, the HOS and MG63 cell lines were treated with quercetin at the indicated concentrations for $24 \mathrm{~h}$. For cell invasion assay, $100 \mu \mathrm{l}$ of HOS and MG63 cells $\left(5 \times 10^{4}\right)$ were seeded in the upper chamber in serum-free media, and $700 \mu \mathrm{l}$ of medium supplemented with $10 \%$ FBS was added to the lower chamber. The cells were then incubated for $24 \mathrm{~h}$ at $37^{\circ} \mathrm{C}$, washed twice with PBS, fixed with methanol, and then stained with crystal violet for $15 \mathrm{~min}$ at room temperature. The cells that adhered to the upper surface of the chamber were carefully removed using cotton swabs, and those on the bottom surface of the membrane were imaged, after which cells in five randomly selected fields were counted under a light microscope at $20 \times$ objective magnification.

RNA isolation and quantitative real-time PCR

Total RNA was extracted using TRIzol (Invitrogen, Barcelona, Spain), according to the manufacturer's instructions, and then reverse-transcribed into cDNA using a PrimeScript RT Reagent Kit (TaKaRa, Japan). Quantitative real-time PCR was performed with SYBR Premix Ex

Table 1. Primer sequences used for qRT-PCR

\begin{tabular}{ll}
\hline Gene & \multicolumn{1}{c}{ Primer } \\
\hline HIF-1 $\alpha$ & 5'- cctatgtagttgtggaagttatgc 3' \\
& 5'- actaggcaatttgctaagaatg -3 \\
VEGF & 5'- cgggaaccagatctctcacc -3' \\
& 5'- aaaatggcgaatccaattcc -3' \\
MMP-2 & 5'- ccaactgcaaaaaaagcctcc -3' \\
& 5'- gtttctcgctcccatttct -3' \\
MMP-9 & 5'- ccctggagacctgagaaccaa-3' \\
& 5'- catctctgccaccccactgta -3' \\
GAPDH & 5'- ctgaacgggaagctcactgg -3' \\
& 5'- tgaggtccaccacctgttg -3' \\
\hline
\end{tabular}


$\mathrm{Taq}^{\mathrm{TM}}$ (TaKaRa) using a StepOne fast real-time PCR system. Target gene expression levels were calculated using $\Delta \Delta \mathrm{Ct}$ and comparative methods after being normalized to GAPDH expression levels. Primers for genes encoding the following proteins were used were used in the experiment: HIF-1 $\alpha$, VEGF, MMP-2, and MMP-9 (Table 1).

\section{Western blot analysis}

The cells were harvested after being treated with quercetin for $24 \mathrm{~h}$ and then washed with PBS. The cells were lysed with RIPA buffer and $1 \times$ protease inhibitor cocktail, and then the lysate was centrifuged at $12,000 \mathrm{rpm}$ for $20 \mathrm{~min}$ to remove debris. The supernatant was preserved at $-80^{\circ} \mathrm{C}$. Protein concentrations were estimated by Bradford assay. The equivalent of $50 \mu \mathrm{g}$ of protein extract was separated by SDS-PAGE and then transferred to polyvinylidene difluoride (PVDF) membranes (pore size: $0.45 \mu \mathrm{m}$, Bio-Rad, Hercules, CA), which were treated with blocking buffer ( $5 \%$ non-fat dry milk) for $1 \mathrm{~h}$ at room temperature before being probed with the following primary antibodies overnight at $4{ }^{\circ} \mathrm{C}$, according to the manufacturer's protocol: rabbit polyclonal anti-HIF-1 $\alpha$ (1:1000, Abcam \#ab 113642, Cambridge, MA, USA), rabbit polyclonal antiVEGFA (1:1000, Abcam \#ab 46154, Cambridge, MA, USA), rabbit polyclonal anti-MMP2 (1:1000, Abcam \#ab 37150, Cambridge, MA, USA), rabbit monoclonal anti-MMP9 (1:1000, Abcam \#ab 86607, Cambridge, MA, USA), and rabbit polyclonal anti-GAPDH (1:3000, Abcam \#ab 9485, Cambridge, MA, USA). The membranes were then washed and incubated with HRP-conjugated secondary anti-mouse IgG antibody (1:5000, Proteintech \#SA00001-1, Wuhan, China) or HRP-conjugated secondary anti-rabbit IgG antibody (1:5000, Proteintech \#SA00001-2, Wuhan, China) for $1 \mathrm{~h}$ at room temperature, after which the blots were detected by an enhanced ECL chemiluminescence system (Bio-Rad) and then quantified by densitometry using ImageJ software.

\section{Animal studies}

A recombinant pLenti-CMV-mCherry-linker-Luc-PGK puro plasmid was packaged into a mature lentivirus with 293T cells, after which the lentivirus was used to infect HOS cells to obtain stable transfectants. For our in vivo tumor experiments, 3-week-old female BALB/c (nu/nu) nude mice were randomly assigned to five groups. After three days, we injected stably transfected HOS cells into the tail vein of each mouse. We then intraperitoneally injected 25,50 or $100 \mathrm{mg} / \mathrm{kg}$ quercetin into the mice in the corresponding groups twice daily for a month. Cisplatin was administered at a dose of $2 \mathrm{mg} / \mathrm{kg}$ and served as a positive control. The negative control mice were injected with vehicle (normal saline). Four weeks after treatment, the mice were sacrificed. Specifically, the mice were anesthetized with chloral hydrate and then abdominally injected with D-Luciferin before being killed by cervical dislocation. The lungs were inspected for metastases using bioluminescence imaging and Living Image Software. All of the above procedures and assays were approved by the Institutional Animal Care and Use Committee of Guangzhou Medical University. The inhibition rate was calculated as follows: [(C-T)/C] $\times 100 \%$ (Eq. 1), where $\mathrm{T}$ is the average fluorescence of the treated group, and $\mathrm{C}$ is the average fluorescence of the negative control group.

\section{Statistical analysis}

All the experiments were performed three times, and the data were expressed as the mean \pm standard deviation. SPSS version 17 was used to perform the statistical analyses, and the results were analyzed using one-way ANOVA and Student's t-test. $\mathrm{P}<0.05$ was considered statistically significant.

\section{Results}

Effects of quercetin on proliferation, apoptosis and cell cycle activity in HOS and MG63 cells

We used a CCK-8 assay to test the effects of various concentrations of quercetin $(25,50$, and $100 \mu \mathrm{M}$ ) in HOS and MG63 cells. HOS and MG63 cell viability did not change in cells that were treated with 25,50 or $100 \mu \mathrm{M}$ quercetin and subsequently assessed at different time points compared with cells treated with media only (Fig. 1). We subsequently investigated cell cycle activity and cell apoptosis using flow cytometry. As shown in Fig. 2 and 3, treatment 


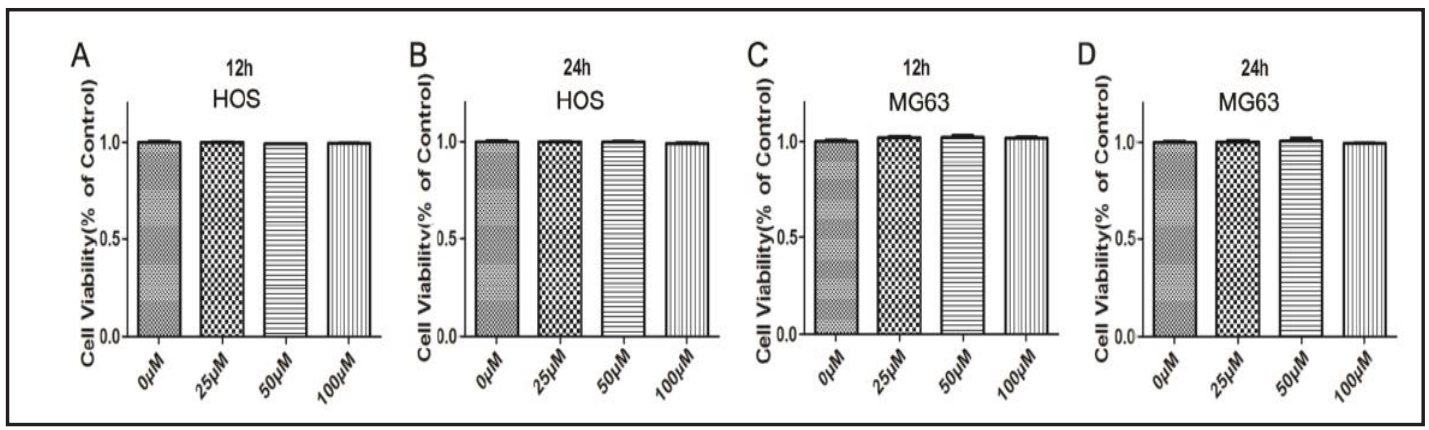

Fig. 1. Effects of quercetinon HOS and MG63 cell proliferation. The indicated cells were seeded in a 24-well plate at a density of $5 \times 10^{4}$ cells/well. After incubating for $6 \mathrm{~h}$, the cells were treated with quercetinat different concentrations $(0,25,50$ and $100 \mu \mathrm{M})$ and then incubatedfor $12 \mathrm{~h}$ and $24 \mathrm{~h}$. Cell viability was detected by a CCK-8 assay in cells treated with various concentrations of quercetin $(0,25,50$ and $100 \mu \mathrm{M}), \mathrm{n}=3$, $* \mathrm{P}<0.05$.

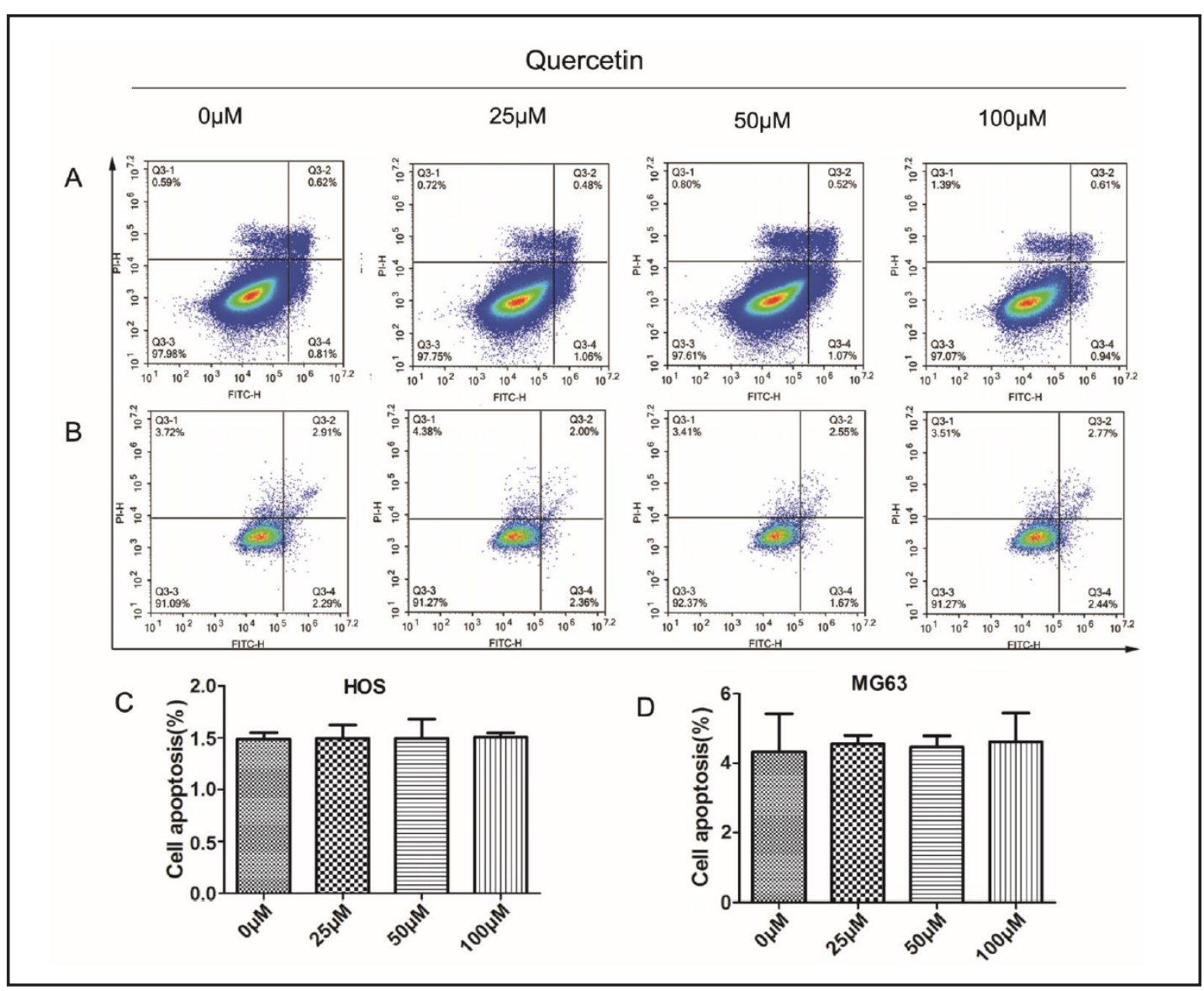

Fig. 2. Effects of quercetin on HOS and MG63 cell apoptosis. The indicated cells were seededin a 24-well plate at a density of $5 \times 10^{4}$ cells/well and then treated with quercetin for $24 \mathrm{~h}$. Ten plates of HOS and MG63 cells were harvested, and cell apoptosis was detected by flow cytometry, $n=3,{ }^{*} \mathrm{P}<0.05$.

with various concentrations of quercetin $(0,25,50,100 \mu \mathrm{M})$ failed to induce cell cycle arrest and cell apoptosis in HOS and MG63 cells, indicating that quercetin has no anti-proliferative or pro-apoptotic effects. We next assessed the effects of quercetin on cell migration and invasion in HOS and MG63 cells. 


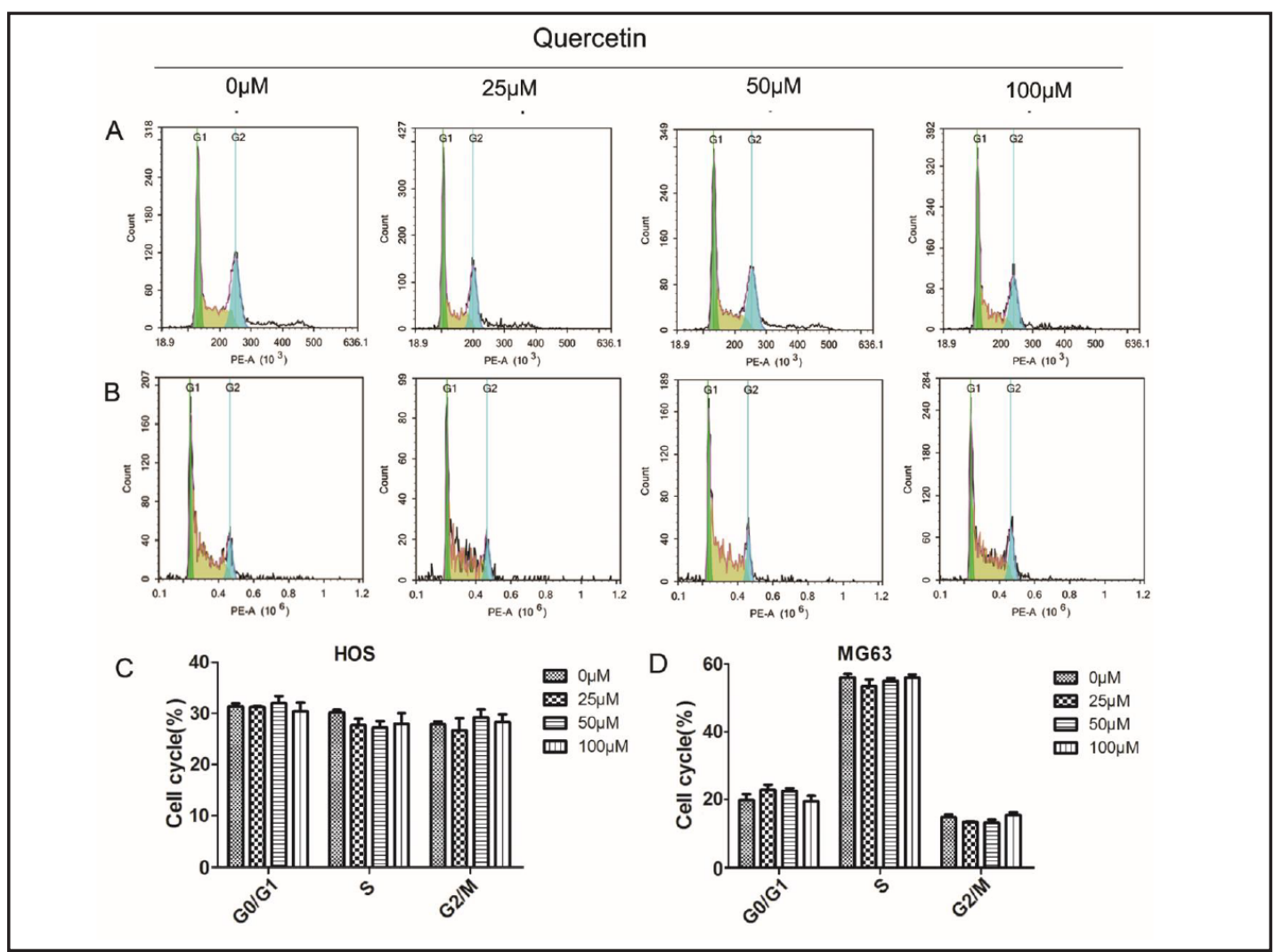

Fig. 3. Effects of quercetin on HOS and MG63 cell cycle activity. The indicated cells were seeded in a 24-well plate at a density of $5 \times 10^{4}$ cells/well and then treated with quercetin for $24 \mathrm{~h}$. Ten plates of HOS and MG63 cells were harvested, and apoptosis was detected by flow cytometry, $\mathrm{n}=3,{ }^{*} \mathrm{P}<0.05$.

Fig. 4. Quercetin inhibits HOS cell migration. The indicated cells were seeded in a 24-well plate at a density of $5 \times 10^{4}$ cells/well and then exposed to quercetin for $24 \mathrm{~h}$. Cell migration was detected by wound healing assay in cells treated with various concentrations of quercetin $(0,25,50$ and 100 $\mu \mathrm{M}$ ) for 12 and $24 \mathrm{~h}$, $\mathrm{n}=3, * \mathrm{P}<0.05$.

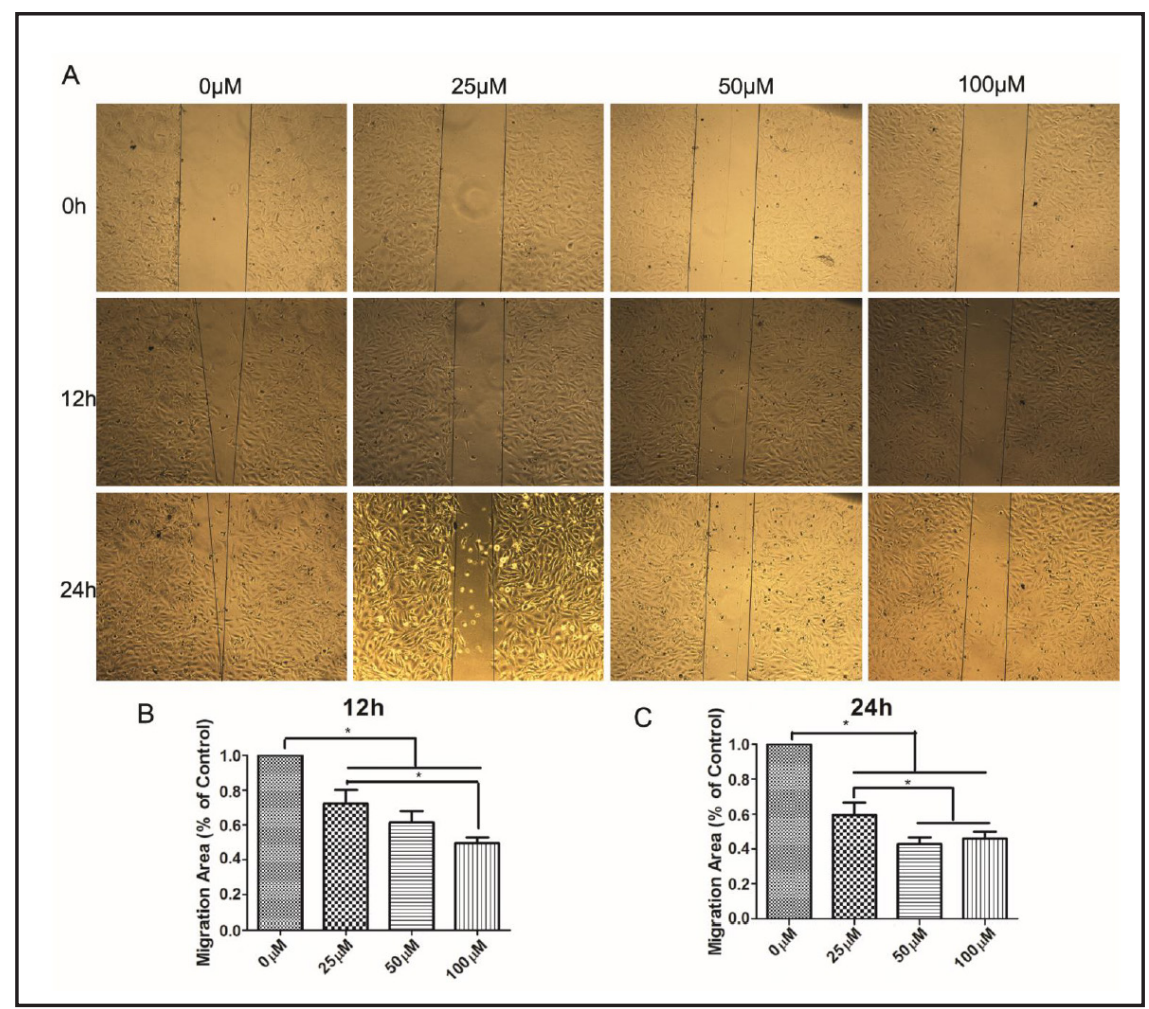


Fig. 5. Quercetin inhibits MG63 cell migration. The indicated cells were seeded in a 24-well plate at a density of $5 \times 10^{4}$ cells/well and then exposed to quercetin for $24 \mathrm{~h}$. Cell migration was detected by wound healing assay in cells treated with various concentrations of quercetin $(0,25,50$ and $100 \mu \mathrm{M}$ ) for 12 and $24 \mathrm{~h}, \mathrm{n}=3$, ${ }^{*} \mathrm{P}<0.05$.

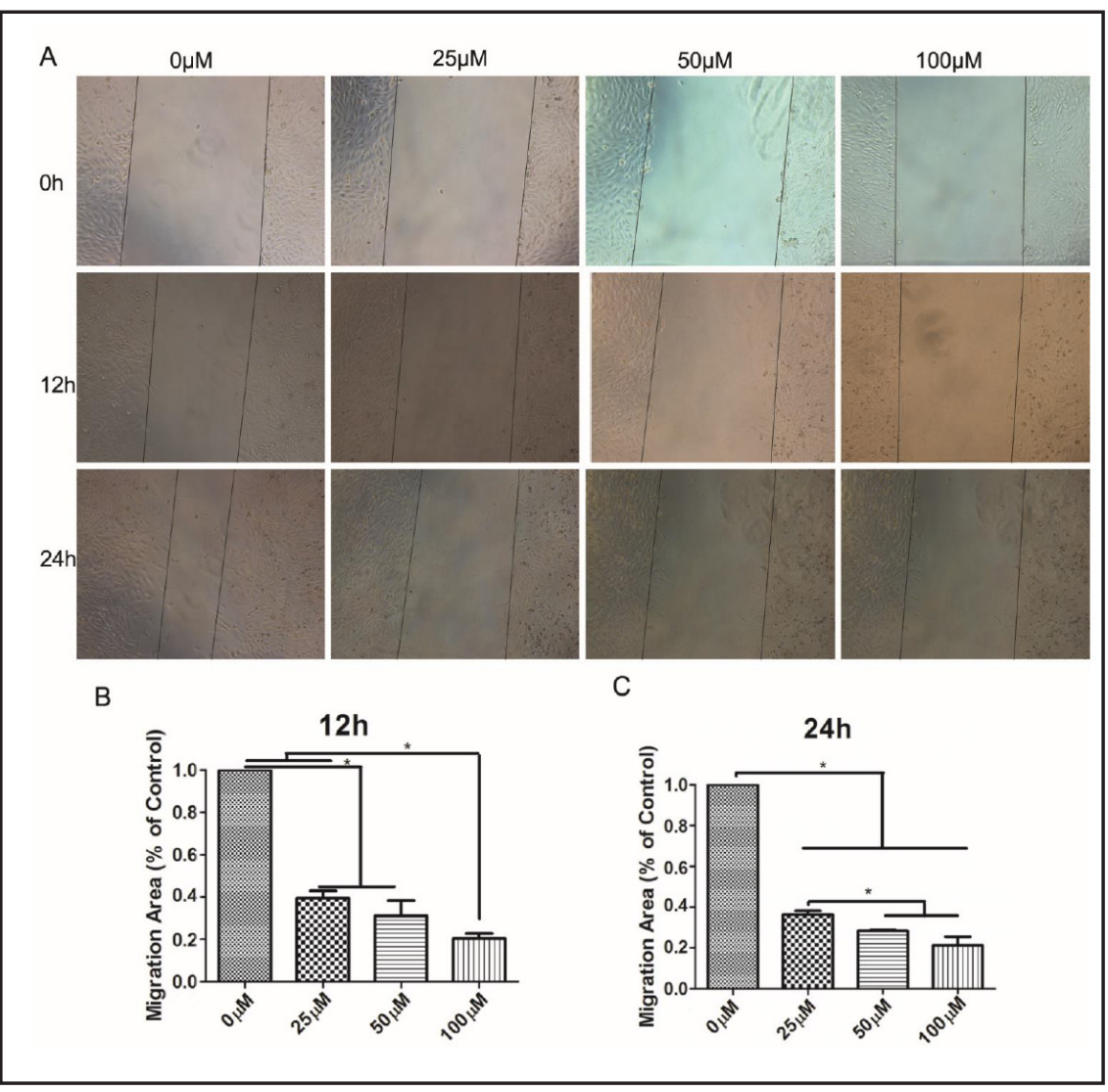

Fig. 6. Quercetin inhibits HOS cell invasion. For cell invasion assay, $100 \mu \mathrm{l}$ of HOS and MG63 cells $\left(5 \times 10^{4}\right)$ were seeded in the upper chamber of a transwell apparatus in serumfree media for $24 \mathrm{~h}$. Cell invasion was detected by transwell assay. $\mathrm{n}=3,{ }^{*} \mathrm{P}<0.05$.

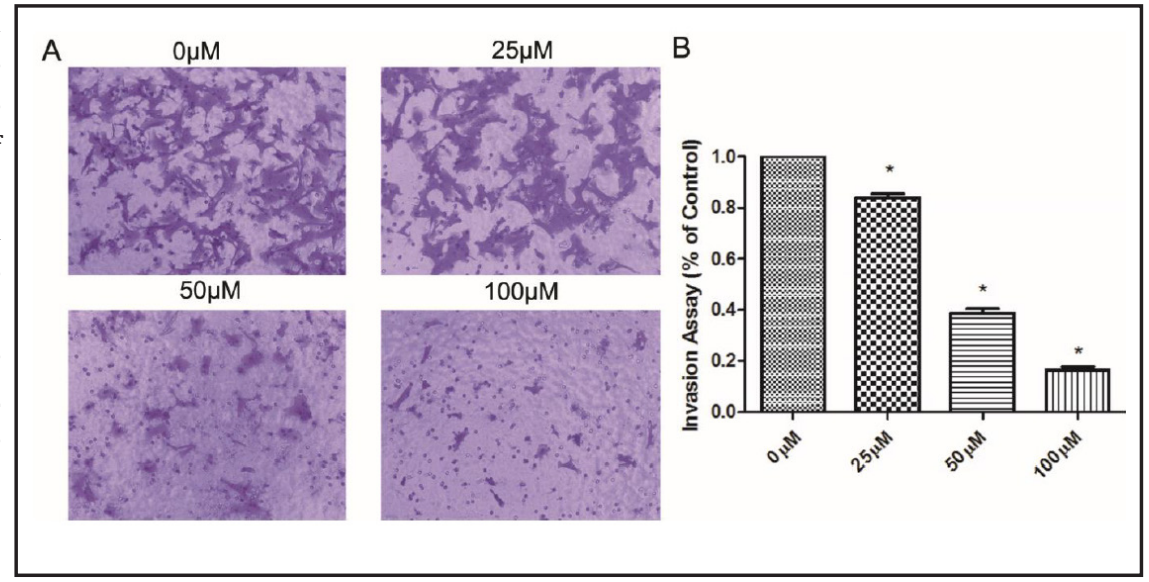

\section{Quercetin inhibits HOS and MG63 cell migration}

To evaluate the effects of quercetin on osteosarcoma cell migration, we performed wound healing assay. For this experiment, HOS and MG63 cells were cultured and then coincubated with different doses $(0,25,50$ and $100 \mu \mathrm{M})$ of quercetin for various time intervals $(0,12$ and $24 \mathrm{~h})$. Treatment with various doses of quercetin for 12 and $24 \mathrm{~h}$ significantly decreased cell migration rates in both cells lines (as shown in Fig. 4, treatment with 25,50 and $100 \mu \mathrm{M}$ quercetin for 12 and $24 \mathrm{~h}$ decreased HOS cell migration rates in the corresponding cells to levels that were $72.28 \pm 22.34 \%, 61.49 \pm 19.61 \%$, and $49.66 \pm 9.33 \%$ and $59.40 \% \pm 20.13 \%, 42.78 \pm 11.34 \%$, and $46.06 \pm 11.5 \%$ of those in cells treated with $0 \mu \mathrm{M}$ quercetin, respectively; as shown in Fig. 5, treatment with 25, 50 and $100 \mu \mathrm{M}$ quercetin for 12 and $24 \mathrm{~h}$ decreased MG63 cell migration rates in the corresponding cells to levels that were $39.49 \pm 5.9 \%, 31.15 \pm 12.27 \%$, and $20.34 \pm 4.25 \%$ and $36.39 \pm 3.09 \%, 28.43 \pm 0.7 \%$, and 
Fig. 7. Quercetin inhibits MG63 cell invasion. For cell invasion assay, $100 \mu \mathrm{l}$ of HOS and MG63 cells $\left(5 \times 10^{4}\right)$ were seeded in the upper chamber of a transwell apparatus in serum-free media for $24 \mathrm{~h}$. Cell invasion was detected by transwell assay. $n=3$, $* \mathrm{P}<0.05$.
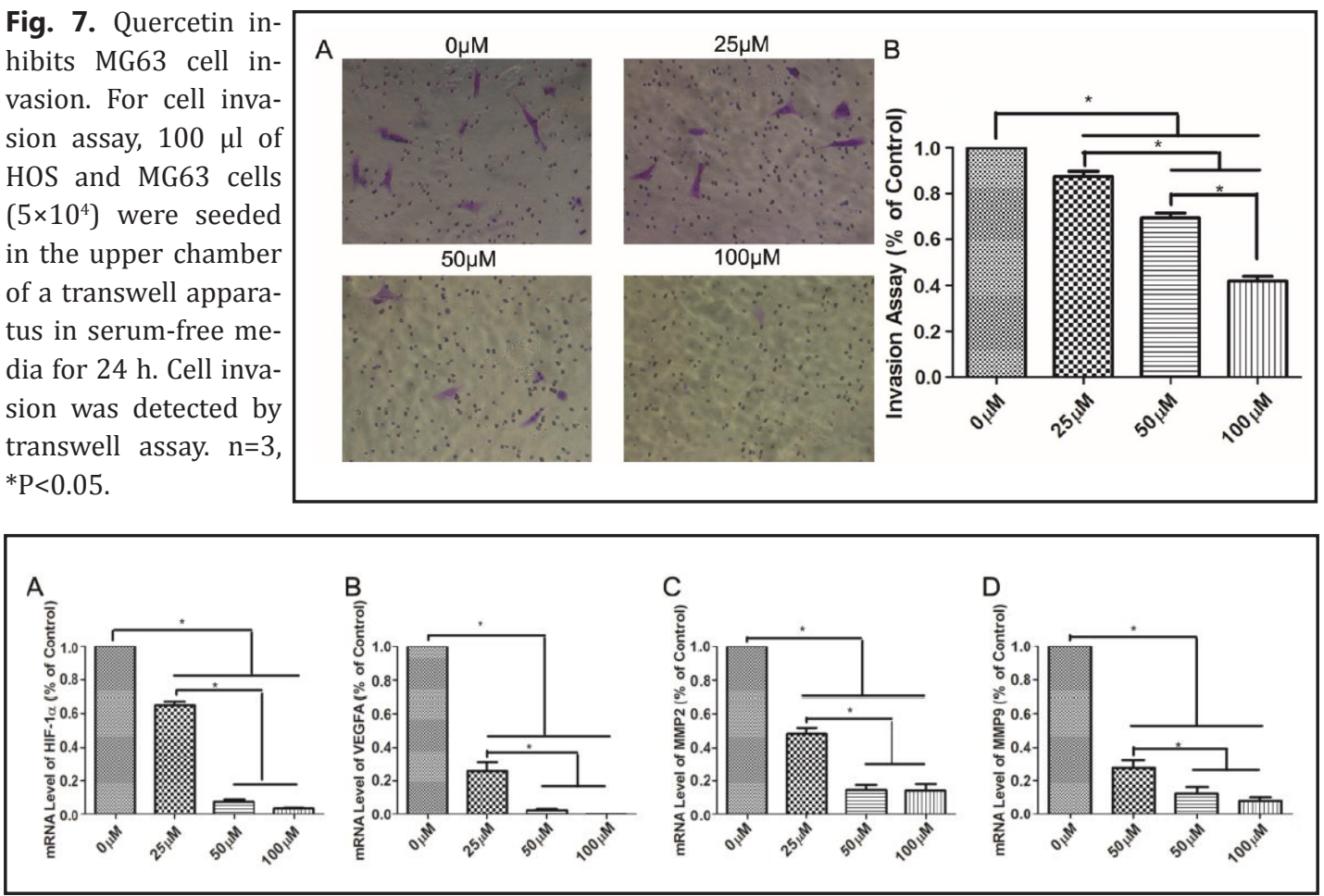

Fig. 8. Quercetin downregulates mRNA expression in HOS cells. The indicated cells were treated with quercetinat different concentrations $(0,25,50$ and $100 \mu \mathrm{M})$ and then incubated for 24 h.Changes in HIF-1 $\alpha$ (A), VEGF (B), MMP2 (C) and MMP9 (D) mRNA expression were detected by quantitative real-time PCR. $n=3$, $* \mathrm{P}<0.05$

$21.26 \pm 7.47 \%$ of those in cells treated with $0 \mu \mathrm{M}$ quercetin, respectively). Moreover, the rate of proliferation inhibition increased as the concentration of quercetin increased. These data showed that quercetin inhibited cell migration in the indicated osteosarcoma cell lines in a dose- and time-dependent manner.

\section{Quercetin inhibits HOS and MG63 cell invasion}

We also examined cell invasion capacity with a three-dimensional Matrigel-coated filter after the indicated cell lines were treated with quercetin. As shown in Fig. 6 and 7, treatment with quercetin significantly decreased cell invasion rates (treatment with 25, 50, and 100 $\mu \mathrm{M}$ quercetin decreased HOS cell invasion rates in the corresponding cells to levels that were $83.98 \pm 2.76 \%, 38.67 \pm 3.52 \%$, and $16.36 \pm 2.56 \%$ of those in cells treated with $0 \mu \mathrm{M}$ quercetin, respectively; treatment with 25, 50 and $100 \mu \mathrm{M}$ quercetin decreased MG63 cell viability in the corresponding cells to levels that were $87.55 \pm 4.98 \%, 69.34 \pm 5 \%$, and $41.98 \pm 4.4 \%$ of those in cells treated with $0 \mu \mathrm{M}$ quercetin, respectively). These results showed that the ability of quercetin-treated HOS and MG63 cells to traverse the Matrigel-coated layer was decreased compared with that of untreated control cells, suggesting that quercetin inhibits HOS and MG63 cell invasion in osteosarcoma in vitro.

Quercetin downregulates mRNA and protein expression in osteosarcoma HOS cells

Several proteins perform primary functions in cancer migration and invasion, including HIF-1 $\alpha$, VEGF, MMP2, and MMP9. Therefore, we assessed the effects of quercetin on the mRNA and protein expression of these proteins by quantitative real-time PCR (Fig. 8) and western blotting (Fig. 9), respectively. We treated HOS cells with various concentrations of quercetin $(0,25,50$ and $100 \mu \mathrm{M})$ for $24 \mathrm{~h}$. The results demonstrated that treatment with 0,25 , 


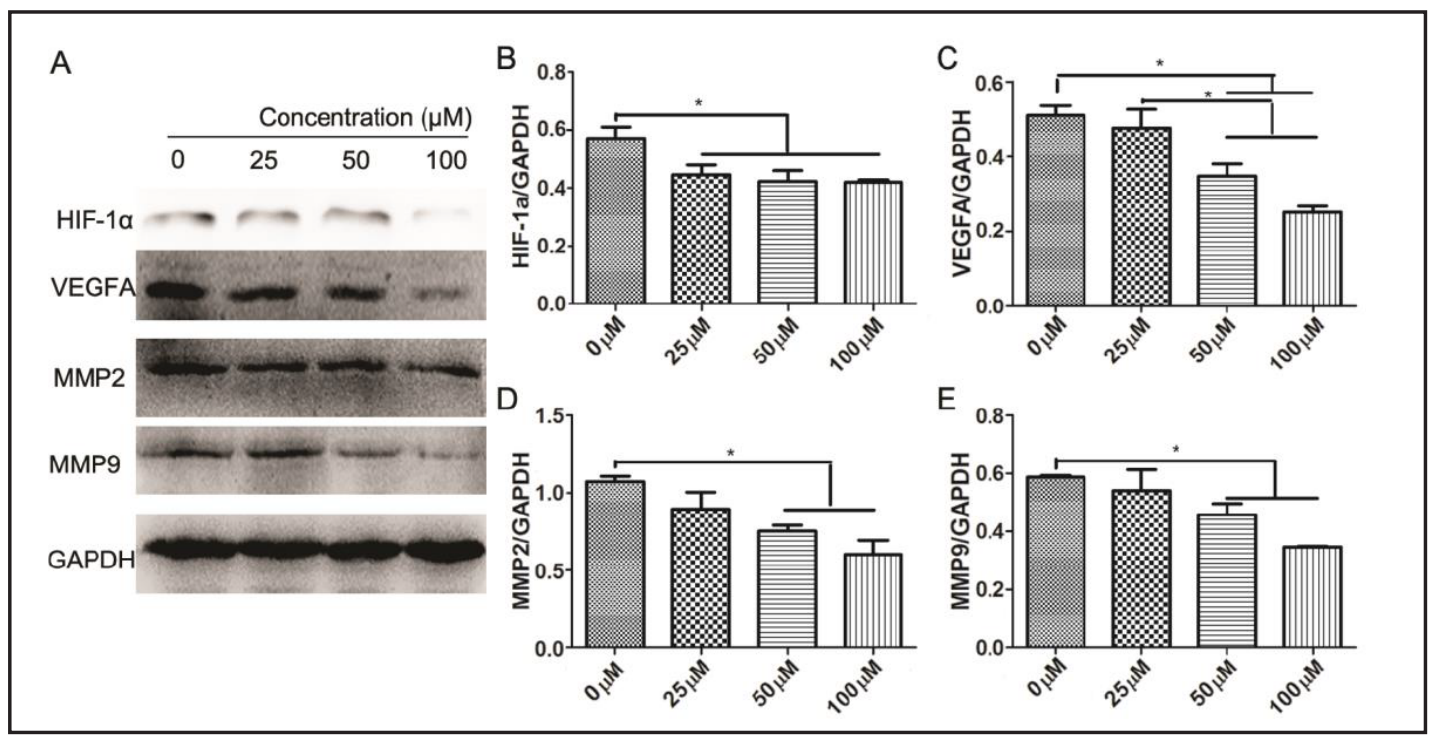

Fig. 9. Quercetin downregulates protein expression in HOS cells. The indicated cells were treated with quercetinat different concentrations $(0,25,50$ and $100 \mu \mathrm{M})$ and then incubated for $24 \mathrm{~h}$. Changes $(\mathrm{A})$ in HIF-1 $\alpha$ (B), VEGF (C), MMP2 (D) and MMP9 (E) protein expression were detected by western blotting. $n=3$, $* \mathrm{P}<0.05$.

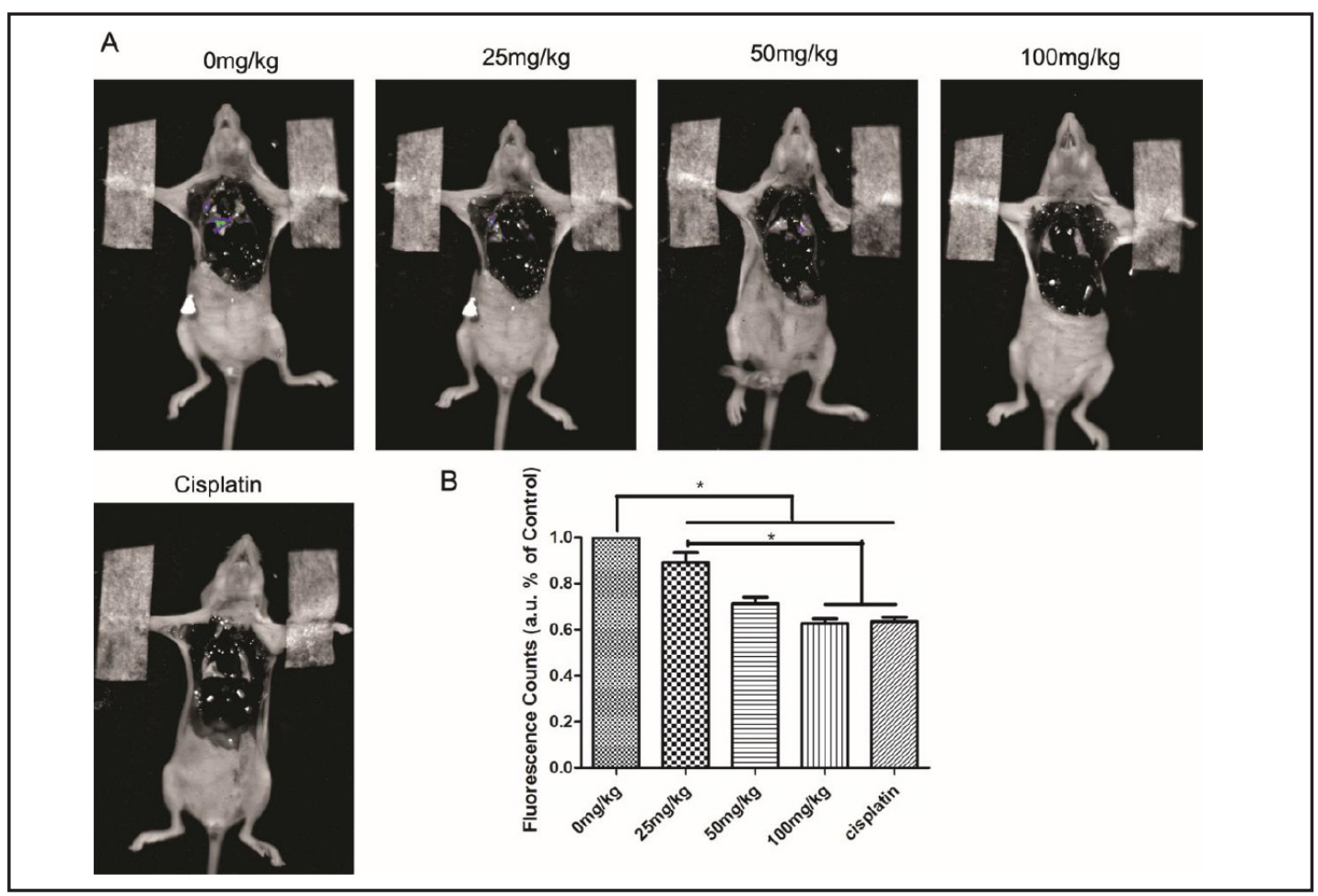

Fig. 10. Quercetin suppresses osteosarcoma cell metastasis in vivo. Mice were injected with stably transfected HOS cells and then treated with quercetin at a dose of 25, 50 and $100 \mathrm{mg} / \mathrm{kg}$ twice daily for a month. Cisplatin was administered at a dose of $2 \mathrm{mg} / \mathrm{kg}$ and served as a positive control. Vehicle (normal saline) served as a negative control. Four weeks thereafter, the mice were sacrificed, and the lungs were inspected for metastases using bioluminescence imaging and Living Image Software. $n=5, * P<0.05$.

50 and $100 \mu \mathrm{M}$ quercetin significantly decreased HIF- $1 \alpha(0.91 \pm 0.07,0.79 \pm 0.13,0.89 \pm 0.04$, and $0.63 \pm 0.05$ of GAPDH, respectively), $\operatorname{VEGF}(0.91 \pm 0.07,0.79 \pm 0.13,0.89 \pm 0.04$, and

\section{KARGER}


$0.63 \pm 0.05$ of GAPDH, respectively), MMP2 $(0.91 \pm 0.07,0.79 \pm 0.13,0.89 \pm 0.04$, and $0.63 \pm 0.05$ of GAPDH, respectively), and MMP9 $(0.91 \pm 0.07,0.79 \pm 0.13,0.89 \pm 0.04$ and $0.63 \pm 0.05$ of GAPDH, respectively) mRNA and protein expression in a dose-dependent manner in HOS cells compared with treatment with controls.

\section{Quercetin suppresses osteosarcoma cell metastasis in vivo}

To determine whether treatment with quercetin affects osteosarcoma in vivo, we injected stably transfected HOS cells into the tail veins of nude mice. Three days after implantation, the animals were treated with quercetin or an equivalent volume of normal saline. Cisplatin, a platinum-based chemotherapy drug used for the treatment of various cancers, was used as a positive control. As shown in Fig. 10, quercetin significantly inhibited tumor growth in the lung in a dose-dependent manner (treatment with 25, 50 and $100 \mathrm{mg} / \mathrm{kg}$ quercetin decreased tumor growth in the corresponding group of mice to levels that were $0.89 \pm 0.10,0.71 \pm 0.06$, and $0.63 \pm 0.05$ of that in mice treated with saline, respectively; treatment with cisplatin decreased tumor growth in the corresponding group of mice to a level that was $0.63+0.04$ of that in mice treated with saline). The tumor inhibition rate was calculated according to Eq. 1. Treatment with $100 \mathrm{mg} / \mathrm{kg}$ quercetin decreased tumor growth by $37.41 \%$, and treatment with cisplatin decreased tumor growth by $36.46 \%$ compared with treatment with saline. These results indicated that quercetin could ameliorate tumor metastasis in vivo.

\section{Discussion}

Osteosarcoma is highly metastatic and invades bone and soft tissue locally and frequently metastasizes to the lungs [38, 39]. Conventional therapies for osteosarcoma may induce drug-resistance and are also associated with a variety of side effects. Therefore, novel therapies for osteosarcoma are urgently needed [40].

Accumulating evidence suggests that using natural or dietary agents as therapies for cancer, particularly in combination with conventional therapies, may provide clinicians with new options with which they can manage their patients [41-43]. Several epidemiological and preclinical studies have highlighted the potential benefits of using flavonoids for cancer prevention. Osthole has been shown to exert anti-cancer effects via the PTEN/Akt signaling pathway [44], and quercetin is one flavonoid whose effects have been widely reported [45-47]. Quercetin exerts its anticancer effects by inducing cell cycle arrest, apoptosis, and differentiation and by suppressing MMP secretion [48]. Moreover, quercetin also reduces tumor cell adhesion, invasiveness, metastasis, and angiogenesis $[49,50]$. Therefore, we aspired to evaluate the effects of quercetin on tumor migration and invasion. However, little is known about the mechanisms underlying the therapeutic effects of quercetin, and studies regarding the effects of quercetin on cell migration and invasion in osteosarcoma are lacking. Thus, the present study aimed to determine the effects of quercetin in the HOS and MG63 cell lines and to elucidate the mechanism underlying its effects. Our results showed that quercetin could suppress osteosarcoma cell migration and invasion in a dose- and time-dependent manner by decreasing HIF-1 $\alpha$, VEGF, MMP2 and MMP9 expression. Furthermore, our results also showed that quercetin could ameliorate tumor metastasis in vivo.

The microenvironments that facilitate tumor establishment and metastasis, particularly those characterized by hypoxia, are well-characterized [51]. Many studies have demonstrated the significance of tumor hypoxia, a phenomenon associated with increased invasion and metastasis, poor patient survival, and increased resistance to therapy [52-54]. HIF, which exists as a heterodimer with two subunits, is a key molecular regulator. HIF $\alpha$ (isoforms HIF $1 \alpha, 2 \alpha, 3 \alpha$ ) and its corresponding beta subunit, HIF $\beta$, are constitutively expressed [55]. HIF-1 $\alpha$ has been shown to be correlated with tumor grade, metastasis, and poor outcomes in various cancers [56], and the absence of HIF-1 $\alpha$ in malignant cells significantly attenuates tumor progression and metastasis [57, 58]. HIF- 
$1 \alpha$ has been found to be expressed in 13 types of human cancers, including lung, prostate, pancreas, breast, and brain cancers [56, 59]. Increased HIF-1 $\alpha$ expression activates a broad array of genes involved in tumor growth, glycolytic switching, angiogenesis, cell invasion and migration, and EMT $[60,61]$. HIF-1 $\alpha$ expression levels were elevated in pancreatic cancer and were correlated with clinical stage and lymph node metastasis [62]. Upregulation of HIF- $1 \alpha$ and its downstream effectors in PC3 cells resulted in increased cell proliferation and migration, as well as the development of chemotherapeutic resistance [33]. Several clinical studies have shown that HIF- $1 \alpha$ is associated with the prognosis and clinicopathological characteristics of osteosarcoma; however, the results of these studies were inconsistent. This study demonstrated that HIF-1 $\alpha$ was expressed in osteosarcoma cells and that quercetin could downregulate HIF- $1 \alpha$ mRNA and protein expression, indicating that quercetin plays a vital role in regulating HIF- $1 \alpha$ and that inhibiting HIF- $1 \alpha$ may be an attractive strategy for combating the tumor microenvironment.

To elucidate the mechanism underlying the effects of HIF- $1 \alpha$ in osteosarcoma, we assessed the expression of its downstream genes. HIF-1 $\alpha$ has been shown to induce the expression of a battery of genes that promote cancer invasion and metastasis, such as VEGF and the MMPs [63]. VEGF, which is downstream of HIF-1 $\alpha$, plays an essential role in cancer cell proliferation and metastasis, processes that are necessary for tumor formation [64]. Current data indicate that high levels of circulating VEGF are an indicator of a poor prognosis in several cancers. Downregulation of VEGF leading to inhibition of tumor cell proliferation and migration has been described in vivo studies involving rats. Furthermore, studies have shown that blocking VEGF inhibited angiogenesis and tumor development and metastasis. A drug targeting VEGF was evaluated in a clinical trial and was found to have impressive positive effects on patients with cancer [65]. Additional evidence indicates that the anticancer effects of quercetin are tied to its ability to modulate the effects of VEGF on tumor invasion and migration. In melanoma, quercetin inhibited STAT3 signaling and downregulated VEGF to attenuate cell growth, migration, and invasion [66]. In a study utilizing RF/6A mice, quercetin attenuated VEGF-induced cell proliferation, migration, and tube formation [67]. Thus, quercetin inhibits metastasis and may be useful in chemoprevention, as well as in anticancer therapy. To determine whether quercetin could inhibit HIF- $1 \alpha$-induced VEGF expression in osteosarcoma, we examined VEGF expression by real-time PCR and western blotting. Our data showed that treating HOS cells with quercetin resulted in a dose-dependent decrease in VEGF expression, indicating that quercetin exerts its anticancer effects by downregulating VEGF expression.

Tumor invasion and metastasis is a rather sophisticated process and is often correlated with ECM hydrolysis, a process mediated by several proteolytic enzymes, including MMPs, which are proteinases involved in the migration and invasion of malignant cells [68]. The MMPs are a family in the metzincin group of enzymes comprising proteases that share a conserved zinc-binding motif, which is located in the catalytic active site and plays a crucial role in reconstructing tissues adjacent to the proliferating cells of malignant neoplasms during cancer metastasis. There are more than 20 MMPs, major enzymes involved in degrading ECM components. Among the MMPs, MMP2 and MMP9 are critical for the initiation of metastasis and invasion [69]. A large number of studies have investigated the prognostic value of MMPs in various metastatic cancers $[70,71]$. Some researchers have demonstrated that a methanolic extract significantly inhibited the adhesion, migration, and invasion of MCF-7 cells in part by inhibiting the activity of MMP2 and MMP9 [72]. Some other studies have shown that the inhibition of metastasis by Paris saponin VII may be associated with changes in MMP2 and MMP9 activity during osteosarcoma progression [73]. Previous studies have affirmed that MMP stimulation is correlated with increased tumor metastatic potential [74, 75]. Therefore, we assessed MMP2 and MMP9 expression in HOS cells treated with quercetin. We found that MMP2 and MMP9 expression was significantly attenuated in osteosarcoma cells treated with quercetin for $24 \mathrm{~h}$. These results indicated that quercetin may exert its

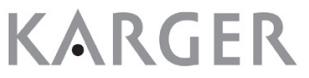


anti-migratory and anti-invasion effects by regulating MMP2 and MMP9 expression.

Finally, we successfully constructed a recombinant lentiviral vector containing luciferase and used the vector to infect HOS cells. Nude mice injected with 0, 25, 50, and $100 \mathrm{mg} /$ $\mathrm{kg}$ quercetin experienced concentration-dependent changes in tumor growth. Specifically, treatment with higher concentrations of quercetin resulted in smaller increases in tumor growth. When the indicated cells were treated with $100 \mu \mathrm{M}$ quercetin, a definite decrease in tumor growth was observed. Taken together, these findings suggest that quercetin plays a crucial role in attenuating metastasis in osteosarcoma.

In conclusion, all of these data suggest that quercetin has inhibitory effects in human osteosarcoma, and our findings indicate that quercetin may be useful as a therapy against human osteosarcoma because of its favorable anticancer effects.

\section{Disclosure Statement}

The author declare that there are no conflicts of interest.

\section{References}

1 Rogozhin DV, Bulycheva IV, Konovalov DM, Talalaev AG, Roshchin VY, Ektova AP, Bogoroditsky YU, Strykov VA, Kazakova AN, Olshanskaya YU, Kachanov DY, Tereshchenko GV: [Classical osteosarcoma in children and adolescent]. Arkh Patol 2015;77:68-74.

2 Osborne TS, Khanna C: A review of the association between osteosarcoma metastasis and protein translation. J Comp Pathol 2012;146:132-142.

3 Bielack SS, Carrle D, Hardes J, Schuck A, Paulussen M: Bone tumors in adolescents and young adults. Curr Treat Options Oncol 2008;9:67-80.

4 Hegyi M, Semsei AF, Jakab Z, Antal I, Kiss J, Szendroi M, Csoka M, Kovacs G: Good prognosis of localized osteosarcoma in young patients treated with limb-salvage surgery and chemotherapy. Pediatr Blood Cancer 2011;57:415-422.

5 Yonemoto T, Hosono A, Iwata S, Kamoda H, Hagiwara Y, Fujiwara T, Kawai A, Ishii T: The prognosis of osteosarcoma occurring as second malignancy of childhood cancers may be favorable: experience of two cancer centers in Japan. Int J Clin Oncol 2015;20:613-616.

6 Chen G, Fang T, Huang Z, Qi Y, Du S, Di T, Lei Z, Zhang X, Yan W: MicroRNA-133a Inhibits Osteosarcoma Cells Proliferation and Invasion via Targeting IGF-1R. Cell Physiol Biochem 2016;38:598-608.

7 Ertug PU, Aydinoglu F, Goruroglu Ozturk 0, Singirik E, Ogulener N: Comparative study of the quercetin, ascorbic acid, glutathione and superoxide dismutase for nitric oxide protecting effects in mouse gastric fundus. Eur J Pharmacol 2013;698:379-387.

8 Vasanthi HR, ShriShriMal N, Das DK: Phytochemicals from plants to combat cardiovascular disease. Curr Med Chem 2012;19:2242-2251.

-9 Kittl M, Beyreis M, Tumurkhuu M, Furst J, Helm K, Pitschmann A, Gaisberger M, Glasl S, Ritter M, Jakab M: Quercetin Stimulates Insulin Secretion and Reduces the Viability of Rat INS-1 Beta-Cells. Cell Physiol Biochem 2016;39:278-293.

10 Gao M, Wang H, Zhu L: Quercetin Assists Fluconazole to Inhibit Biofilm Formations of FluconazoleResistant Candida Albicans in In vitro and In vivo Antifungal Managements of Vulvovaginal Candidiasis. Cell Physiol Biochem 2016;40:727-742.

11 Gim H, Nam JH, Lee S, Shim JH, Kim HJ, Ha KT, Kim BJ: Quercetin Inhibits Pacemaker Potentials via Nitric Oxide/cGMP-Dependent Activation and TRPM7/ANO1 Channels in Cultured Interstitial Cells of Cajal from Mouse Small Intestine. Cell Physiol Biochem 2015;35:2422-2436.

12 Kim H, Moon JY, Ahn KS, Cho SK: Quercetin induces mitochondrial mediated apoptosis and protective autophagy in human glioblastoma U373MG cells. Oxid Med Cell Longev 2013;2013:596496.

-13 El-Gogary RI, Rubio N, Wang JT, Al-Jamal WT, Bourgognon M, Kafa H, Naeem M, Klippstein R, Abbate V, Leroux F, Bals S, Van Tendeloo G, Kamel AO, Awad GA, Mortada ND, Al-Jamal KT: Polyethylene glycol conjugated polymeric nanocapsules for targeted delivery of quercetin to folate-expressing cancer cells in vitro and in vivo. ACS Nano 2014;8:1384-1401. 


\section{Cellular Physiology Cell Physiol Biochem 2017;43:553-567 \begin{tabular}{l|l|l|l} 
DOI: 10.1159/000480528 & (c) 2017 The Author(s). Published by S. Karger AG, Basel \\
www.karger.com/cpb
\end{tabular}

Lan et al.: Quercetin Inhibits Cell Migration and Invasion

14 Brito AF, Ribeiro M, Abrantes AM, Pires AS, Teixo RJ, Tralhao JG, Botelho MF: Quercetin in Cancer Treatment, Alone or in Combination with Conventional Therapeutics? Curr Med Chem 2015;22:3025-3039.

15 Yang F, Song L, Wang H, Wang J, Xu Z, Xing N: Quercetin in prostate cancer: Chemotherapeutic and chemopreventive effects, mechanisms and clinical application potential (Review). Oncol Rep 2015;33:2659-2668.

16 Zhang JY, Lin MT, Zhou MJ, Yi T, Tang YN, Tang SL, Yang ZJ, Zhao ZZ, Chen HB: Combinational Treatment of Curcumin and Quercetin against Gastric Cancer MGC-803 Cells in vitro. Molecules 2015;20:11524-11534.

17 Badowska-Kozakiewicz AM, Budzik MP, Przybylski J: Hypoxia in breast cancer. Pol J Pathol 2015;66:337346.

18 Bourseau-Guilmain E, Menard JA, Lindqvist E, Indira Chandran V, Christianson HC, Cerezo Magana M, Lidfeldt J, Marko-Varga G, Welinder C, Belting M: Hypoxia regulates global membrane protein endocytosis through caveolin-1 in cancer cells. Nat Commun 2016;7:11371.

19 Tretter L, Patocs A, Chinopoulos C: Succinate, an intermediate in metabolism, signal transduction, ROS, hypoxia, and tumorigenesis. Biochim Biophys Acta 2016;1857:1086-1101.

20 Yang MH, Wu KJ: TWIST activation by hypoxia inducible factor-1 (HIF-1): implications in metastasis and development. Cell Cycle 2008;7:2090-2096.

21 Cho KH, Yu SL, Cho do Y, Park CG, Lee HY: Breast cancer metastasis suppressor 1 (BRMS1) attenuates TGFbeta1-induced breast cancer cell aggressiveness through downregulating HIF-1alpha expression. BMC Cancer 2015;15:829.

22 Ai Z, Lu Y, Qiu S, Fan Z: Overcoming cisplatin resistance of ovarian cancer cells by targeting HIF-1-regulated cancer metabolism. Cancer Lett 2016;373:36-44.

-23 Miyake K, Yoshizumi T, Imura S, Sugimoto K, Batmunkh E, Kanemura H, Morine Y, Shimada M: Expression of hypoxia-inducible factor-1alpha, histone deacetylase 1, and metastasis-associated protein 1 in pancreatic carcinoma: correlation with poor prognosis with possible regulation. Pancreas 2008;36:e1-9.

24 Kim YS, Shin SI, Kang KL, Chung JH, Herr Y, Bae WJ, Kim EC: Nicotine and lipopolysaccharide stimulate the production of MMPs and prostaglandin E2 by hypoxia-inducible factor-1alpha up-regulation in human periodontal ligament cells. J Periodontal Res 2012;47:719-728.

-25 Seenath MM, Roberts D, Cawthorne C, Saunders MP, Armstrong GR, O’Dwyer ST, Stratford IJ, Dive C, Renehan AG: Reciprocal relationship between expression of hypoxia inducible factor 1alpha (HIF-1alpha) and the pro-apoptotic protein bid in ex vivo colorectal cancer. Br J Cancer 2008;99:459-463.

26 Knaup KX, Jozefowski K, Schmidt R, Bernhardt WM, Weidemann A, Juergensen JS, Warnecke C, Eckardt $\mathrm{KU}$, Wiesener MS: Mutual regulation of hypoxia-inducible factor and mammalian target of rapamycin as a function of oxygen availability. Mol Cancer Res 2009;7:88-98.

27 Warner TD, Mitchell JA: HIF, stretching to get control of VEGF. Clin Sci (Lond) 2003;105:393-394.

28 Decio A, Taraboletti G, Patton V, Alzani R, Perego P, Fruscio R, Jurgensmeier JM, Giavazzi R, Belotti D: Vascular endothelial growth factor c promotes ovarian carcinoma progression through paracrine and autocrine mechanisms. Am J Pathol 2014;184:1050-1061.

-29 Hiratsuka S, Nakamura K, Iwai S, Murakami M, Itoh T, Kijima H, Shipley JM, Senior RM, Shibuya M: MMP9 induction by vascular endothelial growth factor receptor-1 is involved in lung-specific metastasis. Cancer Cell 2002;2:289-300.

30 Deryugina EI, Quigley JP: Matrix metalloproteinases and tumor metastasis. Cancer Metastasis Rev 2006;25:9-34.

-31 Egeblad M, Werb Z: New functions for the matrix metalloproteinases in cancer progression. Nat Rev Cancer 2002;2:161-174.

32 Clark IM, Swingler TE, Sampieri CL, Edwards DR: The regulation of matrix metalloproteinases and their inhibitors. Int J Biochem Cell Biol 2008;40:1362-1378.

-33 Pei S, Yang X, Wang H, Zhang H, Zhou B, Zhang D, Lin D: Plantamajoside, a potential anti-tumor herbal medicine inhibits breast cancer growth and pulmonary metastasis by decreasing the activity of matrix metalloproteinase-9 and -2. BMC Cancer 2015;15:965.

34 Gebhard C, Fuchs-Baumgartinger A, Razzazi-Fazeli E, Miller I, Walter I: Distribution and activity levels of matrix metalloproteinase 2 and 9 in canine and feline osteosarcoma. Can J Vet Res 2016;80:66-73.

-35 Poudel B, Ki HH, Luyen BT, Lee YM, Kim YH, Kim DK: Triticumoside induces apoptosis via caspasedependent mitochondrial pathway and inhibits migration through downregulation of MMP2/9 in human lung cancer cells. Acta Biochim Biophys Sin (Shanghai) 2016;48:153-160. 


\section{Cellular Physiology Cell Physiol Biochem 2017;43:553-567 \begin{tabular}{l|l|l|l}
\hline DOI: 10.1159/000480528 2017 The Author(s). Published by S. Karger AG, Basel & (O)
\end{tabular}

Lan et al.: Quercetin Inhibits Cell Migration and Invasion

-36 Salem N, Kamal I, Al-Maghrabi J, Abuzenadah A, Peer-Zada AA, Qari Y, Al-Ahwal M, Al-Qahtani M, Buhmeida A: High expression of matrix metalloproteinases: MMP-2 and MMP-9 predicts poor survival outcome in colorectal carcinoma. Future Oncol 2016;12:323-331.

-37 Zeng R, Huang JP, Li XF, Xiong WB, Wu G, Jiang ZJ, Song SJ, Li JQ Zheng YF, Zhang JR: Epb4113 suppresses esophageal squamous cell carcinoma invasion and inhibits MMP2 and MMP9 expression. Cell Biochem Funct 2016;34:133-141.

-38 Murray E, Provvedini D, Curran D, Catherwood B, Sussman H, Manolagas S: Characterization of a human osteoblastic osteosarcoma cell line (SAOS-2) with high bone alkaline phosphatase activity. J Bone Miner Res 1987;2:231-238.

39 Chen X, Yang TT, Wang W, Sun HH, Ma BA, Li CX, Ma Q, Yu Z, Fan QY: Establishment and characterization of human osteosarcoma cell lines with different pulmonary metastatic potentials. Cytotechnology 2009;61:37-44.

40 Ando K, Heymann MF, Stresing V, Mori K, Redini F, Heymann D: Current therapeutic strategies and novel approaches in osteosarcoma. Cancers (Basel) 2013;5:591-616.

41 Huczynski A: Polyether ionophores-promising bioactive molecules for cancer therapy. Bioorg Med Chem Lett 2012;22:7002-7010.

42 Chinembiri TN, du Plessis LH, Gerber M, Hamman JH, du Plessis J: Review of natural compounds for potential skin cancer treatment. Molecules 2014;19:11679-11721.

43 Tang C, Li C, Zhang S, Hu Z, Wu J, Dong C, Huang J, Zhou HB: Novel Bioactive Hybrid Compound Dual Targeting Estrogen Receptor and Histone Deacetylase for the Treatment of Breast Cancer. J Med Chem 2015;58:4550-4572.

44 Wang L, Yang L, Lu Y, Chen Y, Liu T, Peng Y, Zhou Y, Cao Y, Bi Z, Liu T, Liu Z, Shan H: Osthole Induces Cell Cycle Arrest and Inhibits Migration and Invasion via PTEN/Akt Pathways in Osteosarcoma. Cell Physiol Biochem 2016;38:2173-2182.

45 Chirumbolo S: The role of quercetin, flavonols and flavones in modulating inflammatory cell function. Inflamm Allergy Drug Targets 2010;9:263-285.

46 Kashyap D, Mittal S, Sak K, Singhal P, Tuli HS: Molecular mechanisms of action of quercetin in cancer: recent advances. Tumour Biol 2016;10.1007/s13277-016-5184-x

47 Vue B, Chen QH: The Potential of Flavonolignans in Prostate Cancer Management. Curr Med Chem 2016;

48 Lou G, Liu Y, Wu S, Xue J, Yang F, Fu H, Zheng M, Chen Z: The p53/miR-34a/SIRT1 Positive Feedback Loop in Quercetin-Induced Apoptosis. Cell Physiol Biochem 2015;35:2192-2202.

49 Kim GT, Lee SH, Kim JI, Kim YM: Quercetin regulates the sestrin 2-AMPK-p38 MAPK signaling pathway and induces apoptosis by increasing the generation of intracellular ROS in a p53-independent manner. Int J Mol Med 2014;33:863-869.

50 Carrasco-Pozo C, Tan KN, Reyes-Farias M, De La Jara N, Ngo ST, Garcia-Diaz DF, Llanos P, Cires MJ, Borges $\mathrm{K}$ : The deleterious effect of cholesterol and protection by quercetin on mitochondrial bioenergetics of pancreatic beta-cells, glycemic control and inflammation: In vitro and in vivo studies. Redox Biol 2016;9:229-243.

51 Erler JT, Bennewith KL, Cox TR, Lang G, Bird D, Koong A, Le QT, Giaccia AJ: Hypoxia-induced lysyl oxidase is a critical mediator of bone marrow cell recruitment to form the premetastatic niche. Cancer Cell 2009;15:35-44.

52 Vaupel P, Mayer A, Hockel M: Tumor hypoxia and malignant progression. Methods Enzymol 2004;381:335354.

53 Tan EY, Campo L, Han C, Turley H, Pezzella F, Gatter KC, Harris AL, Fox SB: Cytoplasmic location of factorinhibiting hypoxia-inducible factor is associated with an enhanced hypoxic response and a shorter survival in invasive breast cancer. Breast Cancer Res 2007;9:R89.

54 Stegeman H, Kaanders JH, Wheeler DL, van der Kogel AJ, Verheijen MM, Waaijer SJ, Iida M, Grenman R, Span PN, Bussink J: Activation of AKT by hypoxia: a potential target for hypoxic tumors of the head and neck. BMC Cancer 2012;12:463.

55 Majmundar AJ, Wong WJ, Simon MC: Hypoxia-inducible factors and the response to hypoxic stress. Mol Cell 2010;40:294-309.

-56 Zhong H, De Marzo AM, Laughner E, Lim M, Hilton DA, Zagzag D, Buechler P, Isaacs WB, Semenza GL, Simons JW: Overexpression of hypoxia-inducible factor 1 alpha in common human cancers and their metastases. Cancer Res 1999;59:5830-5835. 


\section{Cellular Physiology Cell Physiol Biochem 2017;43:553-567 \begin{tabular}{ll|l|l|l} 
DOI: 10.1159/000480528 & O 2017 The Author(s). Published by S. Karger AG, Basel \\
and Biochemistry
\end{tabular}

Lan et al.: Quercetin Inhibits Cell Migration and Invasion

57 Liao D, Corle C, Seagroves TN, Johnson RS: Hypoxia-inducible factor-1alpha is a key regulator of metastasis in a transgenic model of cancer initiation and progression. Cancer Res 2007;67:563-572.

58 Bertout JA, Patel SA, Simon MC: The impact of 02 availability on human cancer. Nat Rev Cancer 2008;8:967975.

59 Nagaraju GP, Bramhachari PV, Raghu G, El-Rayes BF: Hypoxia inducible factor-1alpha: Its role in colorectal carcinogenesis and metastasis. Cancer Lett 2015;366:11-18.

60 Semenza GL: Hypoxia-inducible factors: mediators of cancer progression and targets for cancer therapy. Trends Pharmacol Sci 2012;33:207-214.

-61 Semenza GL: Molecular mechanisms mediating metastasis of hypoxic breast cancer cells. Trends Mol Med 2012;18:534-543.

62 Miyake K, Nishioka M, Imura S, Batmunkh E, Uto Y, Nagasawa H, Hori H, Shimada M: The novel hypoxic cytotoxin, TX-2098 has antitumor effect in pancreatic cancer; possible mechanism through inhibiting VEGF and hypoxia inducible factor-1alpha targeted gene expression. Exp Cell Res 2012;318:1554-1563.

63 Semenza GL: Targeting HIF-1 for cancer therapy. Nat Rev Cancer 2003;3:721-732.

64 Cuyle PJ, Prenen H: Current and future biomarkers in the treatment of colorectal cancer. Acta Clin Belg 2016;10.1080/17843286.2016.12629961-13.

-65 Papadimitriou K, Rolfo C, Dewaele E, Van De Wiel M, Van den Brande J, Altintas S, Huizing M, Specenier P, Peeters M: Incorporating anti-VEGF pathway therapy as a continuum of care in metastatic colorectal cancer. Curr Treat Options Oncol 2015;16:18.

66 Cao HH, Tse AK, Kwan HY, Yu H, Cheng CY, Su T, Fong WF, Yu ZL: Quercetin exerts anti-melanoma activities and inhibits STAT3 signaling. Biochem Pharmacol 2014;87:424-434.

67 Li F, Bai Y, Zhao M, Huang L, Li S, Li X, Chen Y: Quercetin inhibits vascular endothelial growth factor-induced choroidal and retinal angiogenesis in vitro. Ophthalmic Res 2015;53:109-116.

-68 Loffek S, Schilling 0, Franzke CW: Series "matrix metalloproteinases in lung health and disease": Biological role of matrix metalloproteinases: a critical balance. Eur Respir J 2011;38:191-208.

-69 Zitka O, Kukacka J, Krizkova S, Huska D, Adam V, Masarik M, Prusa R, Kizek R: Matrix metalloproteinases. Curr Med Chem 2010;17:3751-3768.

70 Chen B, Huang Z, Zhang Y, Chen Y, Li Z: MicroRNA-145 Suppresses Osteosarcoma Metastasis via Targeting MMP16. Cell Physiol Biochem 2015;37:2183-2193.

71 Deng B, Feng Y, Deng B: TIPE2 Mediates the Suppressive Effects of Shikonin on MMP13 in Osteosarcoma Cells. Cell Physiol Biochem 2015;37:2434-2443.

72 Manoj GS, Kumar TR, Varghese S, Murugan K: Effect of methanolic and water extract of Leucobryum bowringii Mitt. on growth, migration and invasion of MCF 7 human breast cancer cells in vitro. Indian J Exp Biol 2012;50:602-611.

-73 Cheng G, Gao F, Sun X, Bi H, Zhu Y: Paris saponin VII suppresses osteosarcoma cell migration and invasion by inhibiting MMP2/9 production via the p38 MAPK signaling pathway. Mol Med Rep 2016;14:3199-3205.

74 Meng XN, Jin Y, Yu Y, Bai J, Liu GY, Zhu J, Zhao YZ, Wang Z, Chen F, Lee KY, Fu SB: Characterisation of fibronectin-mediated FAK signalling pathways in lung cancer cell migration and invasion. Br J Cancer 2009;101:327-334.

-75 Jacob A, Jing J, Lee J, Schedin P, Gilbert SM, Peden AA, Junutula JR, Prekeris R: Rab40b regulates trafficking of MMP2 and MMP9 during invadopodia formation and invasion of breast cancer cells. J Cell Sci 2013;126:4647-4658. 